\title{
The Demand for Individual Grievance Procedures in Germany and Spain: Labour Law Changes versus Business Cycle
}

\author{
BERND FRICK \\ Department of Management, UNIVERSITY OF PADERBORN, and Institute of Labour Law and \\ Industral Relations, UNIVERSITY OF TRIER, GERMANY. E-mail: bernd.frick@notes.upb.de
}

MIGUEL A. MALO

Department of Economics and Economic History, UNIVERSITY OF SALAMANCA, SPAIN. Email:malo@usal.es

\section{PILAR GARCÍA MARTÍNEZ}

Department of Applied Economics, UNIVERSITY OF SALAMANCA, SPAIN. E-mail: pilargm@usal.es

\section{MARTIN SCHNEIDER}

Department of Management, UNIVERSITY OF PADERBORN, and Institute of Labour Law and Industral Relations, UNIVERSITY OF TRIER, GERMANY.E-mail: martin.schneider@notes.upb.de

\begin{abstract}
In this article, we analyze the determinants of annual number of grievance procedures, mainly individual complaints against unfair dismissals. Econometric analyses using two balanced panels from the 11 West German states (19642006) and the 17 autonomous regions of Spain (1987-2006) show that labour market characteristics, such as the unemployment and the vacancy rate have a much stronger influence on the cyclical demand for individual grievance procedures than changes in "workers' rights". Thus, the individual costs of unemployment are better predictors of the demand for individual grievance procedures than institutional changes strengthening or weakening employees' rights.

Keywords: Labour Courts, Dismissals, Dismissal Protection, Unemployment, Vacancies.
\end{abstract}

\section{La demanda de reclamaciones laborales individuales en Alemania y España: Derecho Laboral versus Ciclo Económico}

\section{RESUMEN}

En este artículo, se analizan los determinantes del número de procesos de despido individual improcedente. Los análisis econométricos realizados usando dos paneles equilibrados de datos de 11 estados de Alemania del Oeste (1964-2006) y 17 comunidades autónomas de España (1987-2006) muestran que algunas características del mercado de trabajo tales como la tasa de desempleo o la de vacantes tienen una influencia mayor en la demanda cíclica de reclamaciones individuales que los cambios en los derechos de los trabajadores. Así, el coste individual del desempleo predice mejor las reclamaciones por despido y salariales que los cambios institucionales que alteran los derechos de los trabajadores.

Palabras clave: Tribunales Laborales, despidos, protección por despido, desempleo, vacantes.

JEL Classification: J53, J63, K31

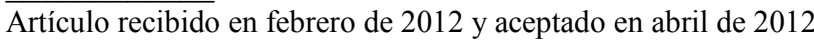

Artículo disponible en versión electrónica en la página www.revista-eea.net, ref. ə-30116 


\section{INTRODUCTION}

The objective of this article is to analyze the relative importance of (changes in) labour law regimes and (changes in) labour market characteristics in explaining labour litigation. During the last decades, most changes in labour law had to do with reducing the extent of employment protection legislation, perhaps one of the most debated issues in labour market policy. Employment protection legislation has been and continues to be a major candidate for explaining the high and persistent unemployment in many of the West European countries (see Addison and Teixeira 2003a; Feldmann 2003; Pierre and Scarpetta 2004). In particular, the German and the Spanish legal frameworks governing individual as well as collective dismissals have been criticized for the "labour market sclerosis" they have allegedly caused over the last three to four decades (for Germany see, inter alia, Berger 1998, for Spain see Bentolila and Dolado, 1994) ${ }^{1}$.

Although a number of papers have tried to find empirical support for this assumption, the available evidence is at best ambiguous. So far, the literature has been dominated by cross-country studies such as Lazear (1990), who investigates the effects of severance pay regulations on employment. Using a sample of 20 countries over the period 1956-1984 he finds that the amount of severance pay is negatively correlated with the employment-population ratio and the labour force participation rate and positively with the unemployment rate. These findings have recently been challenged by Addison and Teixeira (2003b) who, after having extended Lazear's sample period to 1999, find that severance pay has no statistically significant impact on either the labour force participation rate or the employment-population ratio. Moreover, a study by the OECD (1999) concludes that employment protection legislation has no impact on unemployment levels, but significantly reduces inflows into and outflows from unemployment.

One of the major weaknesses of this approach is that the "strictness" of employment protection legislation is usually measured by some additive indices that are likely to misrepresent the costs of a dismissal for various reasons: First, the legal rules may be applicable to a fraction of the workforce only (for example to employees with tenure above a certain minimum threshold, to workers in firms with more than 5 or 10 employees $^{2}$, to workers with open-ended contracts,

\footnotetext{
${ }^{1}$ However, this position has been criticized forcefully already a while ago: [...] time spent worrying about strict labour market regulation, employment protection and minimum wages is probably time largely wasted" (Nickell and Layard 1999: 3080).

2 These different threshold levels have been applied in Germany recently: Until 1995, the minimum number of employees was five, between 1996 and 1998 it was increased to ten. From 1999-2003 it was reduced to five again and, finally, in January 2004 it was again increased to its previous level (see Bauer, Bender and Bonin 2004 and Verick 2004). In Spain, there is no
} 
etc.). Second, although the various national laws usually provide guidelines with respect to the admissibility of lay-offs, the indices used in the studies quoted above do not take into account differences in the effective enforcement of the law by the respective system of labour courts ${ }^{3}$. Finally, economic circumstances, such as the overall labour market situation, and the unemployment benefit system (with the coverage rate, the replacement rate and the maximum duration of benefits as the main characteristics) are likely to affect the behaviour of dismissed employees (i.e. the search behaviour of persons threatened by unemployment is c.p. influenced by the duration of benefit entitlements). Surprisingly, these latter factors have not been taken into account in most analyses of national systems of employment protection legislation.

Moreover, there is very little research on the impact of national labour law systems on the demand for grievance procedures and the activity levels of labour courts. Inadequate or "imprecise" employment protection legislation can foster the strategic use of the different legal procedures available to dismiss a worker, resulting in a widespread "misuse" of disciplinary reasons and a hesitant use of economic reasons. This would, in turn, distort the work of all institutions involved in dismissals, mainly the labour courts (Malo 2000, GarcíaMartínez and Malo 2007) and might even have non-negligible macroeconomic effects (Galdón-Sánchez and Güell 2003). At the same time, the situation on the (regional) labour market can also affect the demand for grievance procedures. The reason here is that the individual costs of becoming unemployed vary with labour market characteristics such as the unemployment and the vacancy rate. Separating the relative importance of labour law regimes and different labour market situations would, first, foster our understanding of the impact of differrent legal regimes on labour market performance. Second, it would focus the political debate about the different effects of employment protection legislation on labour market outcomes in general and on the importance of bureaucratic firing costs associated with the evolution of different systems of grievances procedures.

It is obvious, that an international comparison is the most adequate context for this type of research. By comparing different legislations (including their respective changes over time) we better understand the relevance of employ-

\footnotetext{
threshold for small firms. For a comparison of the Spanish case with the Italian one concerning the absence or presence of such threshold levels see Boeri and Jimeno (2005).

${ }^{3}$ Moreover, the legal framework does not say anything about severance pay and its determinants ("bargaining in the shadow of the law"). Economic intuition suggests that the relevant features of the law should be discernible in the outcomes of negotiations between firms and employees (see Malo 2000 for Spain and Grund 2006a, 2006b as well as Goerke and Pannenberg 2005 for Germany).
} 
ment protection legislation compared with other features of a country's labour market. However, there are two possible designs for such an international comparison: Either using as many countries as possible (as in e.g. Botero et al., 2004, or Chor and Freeman, 2005, for example) or focusing on a small number of countries (as in e.g. Deakin and Sarkar, 2008). In this paper we use the second approach, comparing only the labour law systems and national labour markets of Germany and Spain. The two countries exhibit evident similarities in terms of the main components of their labour law systems but, at the same time, they have rather different labour market outcomes in terms of employment and unemployment. Our intention in this article is to provide a first empirical assessment of the impact of labour market characteristics and labour law regimes on the demand for individual grievance procedures using two balanced regional panels from the two countries. Therefore, we analyze a balanced regional panel covering the 11 West German states during the period 1964-2006 and another balanced regional panel covering the 17 Spanish autonomous communities for the period 1987-2006. Our main objective is to shed some light on the relative importance of labour market developments and labour law changes on the use of different grievance procedures by workers. Our article is closely related to the recent economic literature on employment protection. However, while previous analyses of labour litigation have focused on individual dismissal, we also remuneration cases, an area that did not get much attention in academic research on employment protection. In fact, grievance procedures concerning remuneration are usually not considered part of a nation's employment protection legislation. Nevertheless, these cases are also (potentially) influenced by the business cycle as well as the respective labour law regime. Therefore, empirical analyses looking at the demand for individual grievance procedures concerning dismissals as well as remuneration may provide some hitherto ignored insights into the determinants of labour litigation.

The paper proceeds as follows. We start with a short description of, first, the system of dismissal protection legislation in Germany and Spain and, second, the respective national labour court system (section 2). Our theoretical model, from which we derive a few testable predictions, will be developed in section 3 . This is followed by a description of the data and a presentation of our main findings (section 4). We conclude with a short summary and some policy implycations as well as some implications for further research (section 5).

\section{THE LEGAL FRAMEWORK FOR GRIEVANCE PROCEDURES IN GERMANY AND SPAIN}

\subsection{The Economics of Employment Protection Legislation}

Contrary to the situation in most Anglo-Saxon countries, where legal protection against dismissal is characterized by relatively low expected dismissal costs 
with a high variance, i.e. a high degree of uncertainty, for the parties to the employment contract (Malo and Pérez 2003), the opposite is true for Germany and Spain. In both countries, expected dismissal costs are relatively high, with a low variance although court decisions tend to increase that uncertainty (Eger 2004: 381).

In a world that is characterized by informational asymmetries between employer and worker, positive transaction costs and externalities, legal protection against dismissal is unlikely to evolve spontaneously out of individual or collective negotiations, even if protection is in the interest of both parties (see Eger 2004: 386; Levine 1989, 1991):

- Dismissal protection legislation not only increases the surplus from cooperation between employer and employee but also strengthens the employee's position with respect to the distribution of that surplus.

- If employers are not fully informed about the motivation of job applicants and if there is competition between firms with and without dismissal protection, "talented shirkers" will tend to concentrate in firms offering a "no lay-off policy", i.e. adverse selection may result.

- As long as employers have the opportunity to shift the costs of "excessive use" of their workforce to the social security system (i.e. if there is no experience-rated contribution system) firms have little incentive to voluntarily offer whatever kind of dismissal protection to their employees.

Summarizing, there are a number of reasons not to expect the emergence of a socially efficient system of dismissal protection. This, in turn, does not imply that the systems that can be observed across Europe will have similar or even identical characteristics. In order not to compare apples and oranges, however, we concentrate on two systems that seem to be quite similar with respect to the relatively high dismissal costs they impose on employers.

\subsection{Dismissal Protection Legislation in Germany and Spain}

In Germany, the Dismissal Protection Act (DPA; enacted in 1969) applies to persons working in firms regularly employing more than ten employees and who have been working there without interruption for at least six months. According to this Act an employment relationship can only be terminated by the employer if the dismissal is "socially justified". The law distinguishes between three socially justified reasons for dismissals: Dismissal upon lack of capability (e.g. due to permanent or repeated illness), dismissal upon personal misconduct (e.g. repeated violation of safety regulations) and dismissal upon redundancy (e.g. plant closing).

Dismissals always require notification of the works council, which has the right to object to the dismissal within seven days. If the works council does 
object - a rather rare event - the employer has to wait with the dismissal until the labour court has reached a decision ${ }^{4}$, i.e. the firm has to continue paying the worker's wage. The notice period for terminating an employment contract is at least four weeks for both parties and increases with the employee's tenure up to a maximum of seven months (for employees with more than 20 years of tenure).

In practice, far more than $90 \%$ of all cases are settled either within or outside the court usually ending in a termination of the employment relationship. Although there is no general legal entitlement to severance pay in case of a dismissal, such compensation has become more important recently. Two recent studies report that in the period 1991-2003 (1998-2003), about 12\% (15\%) of all dismissed employees received severance payments (see Goerke and Pannenberg 2005: 33 and Pfarr et al. 2005: 67). The average amount received in that period was about $9,200 €$, with higher amounts being granted in cases of redundancies $(10,400 €)$ than in cases of individual dismissal $(8,600 €)^{5}$. Moreover, not only the probability of receiving a financial compensation, but also the amount increases with the size of the firm that dismisses an employee (in the case of an individual dismissal 4,000 $€$ in firms with 1-5 employees and 15,000 in firms with more than 2,000 employees; in case of redundancies 7,900€ in the former and $12,100 €$ in the latter firm size group) (see again Grund 2006b: 14 and Pfarr et al. 2005: 74).

These figures notwithstanding, severance payments differ considerably and are, therefore, difficult to anticipate for employers as well as employees: In case of individual dismissal upon redundancy no severance payments have to be granted. Only in case of collective dismissals, i.e. when a certain minimum number of employees are affected (Heseler and Mückenberger 1999), management and works council are obliged to negotiate a "social compensation plan" which mainly consists of the severance payments to be granted to the members of the workforce. In this case, no limit is specified by the law. If a dismissal is not socially justified labour courts usually require the employer to grant severance pay (increasing with age and tenure of the workers affected, up to a maximum of 18 gross monthly salaries). Summarizing, the amount of severance pay granted to the worker is in most cases not determined by a labour court, but by negotiations between the two parties to the contract.

Spanish labour law distinguishes between two 'fair causes' for the dismissal of permanent workers ${ }^{6}$ : Disciplinary grounds (e.g. the worker does not carry out his/

\footnotetext{
${ }^{4}$ The presence of a works council has - other things equal - no statistically significant influence on the probability that the dismissed worker takes his employer to court (Pfarr et al. 2005: 111).

${ }^{5}$ Not surprisingly, the most important determinants of the amount of severance pay received are the individual's prior monthly income and his/her tenure with the firm (Pfarr et al. 2005: 69-74).

${ }^{6}$ Permanent workers are employed under an open-ended contract. Legislation makes no distinction with regard to firm size.
} 
her duties properly) and objective grounds (e.g. staff reductions due to economic, technical, organizational or production reasons). The latter kind of dismissal must affect less than $10 \%$ of a firm's total workforce ${ }^{7}$; otherwise, the firm is obliged to follow the administrative procedures enacted to govern collective dismissals. Here, there are two additional requirements. First, mandatory advance notice of workers is obligatory (a period of 30 days), although firms can substitute for this by paying the corresponding wages (this is not required in the case of dismissals that are due to disciplinary reasons). Second, written notice to the worker is also required, citing the reason(s) for dismissal. In case of objective grounds, firms should offer the worker the regular severance pay (20 days per year of service) together with the written notification.

In practice, most dismissals are justified with disciplinary reasons as there are fewer requirements involved. Moreover, the interpretation by judges of what constitutes proper "economic grounds" is controversial, because judges have to evaluate the "severity" of the economic reasons brought forward to dismiss a worker. This, however, is not a legal, but a management issue (Malo 2000). In 1997, the legal definition of economic grounds was (further) specified to facilitate their use by the courts. Nevertheless, the application of the concept of "economically justified dismissals" is still subject to a high degree of legal uncertainty. Therefore, the probability of a court's decision declaring the dismissal as "unfair" (even in cases where economic grounds do exist) is quite high ${ }^{8}$.

The costs of a dismissal differ with the reasons cited and their consideration by the judges involved. In case of a 'fair' dismissal (procedente) on objective, i.e. economic grounds severance pay amounts to 20 days per year of service (with an upper limit of 12 months). In case of a disciplinary dismissal no such costs occur. In case of an 'unfair' dismissal (improcedente) these costs are much higher. Here the severance pay to which the worker is entitled is 45 days per year of service, with an upper limit of 42 months. The firm can re-hire the dismissed worker, thereby avoiding the severance payment. This, however, is a very rare event. In 1997, a new form of an open-ended contract was introduced stipulating a much lower severance pay (33 days per year of service) for dismissals on economic grounds that had been declared as unfair by the courts. As the costs of an unfair dismissal on disciplinary reason remained constant at 45 days even under the new regime, this type of a permanent contract will only result in lower firing costs if

7 This requirement was introduced with the 1994 reform of Spanish labour law. Before that, labour law permitted only one such dismissal in firms with less than 50 workers at a particular point in time.

8 The two most recent legal reforms of the Spanish labour market launched in October 2010 and February have tried to change this predominance of unfair individual dismissals. Both reforms are beyond the scope of the data used in this article. Nevertheless, see García-Serrano et al. (2011) and Malo (2012) for a review of both reforms. 
there is a sufficiently large and convincing number of economic (instead of disciplinary) reasons that can be cited by the firm ${ }^{9}$.

When a dismissal is considered 'unfair' (either directly by the court or indirectly by the firm in a pre-trial agreement), the company also has to pay the 'intervening wage' ('salarios de tramitación'), i.e. the wage that would have accrued to the worker in the time between the date of the dismissal and the judicial decision. In case the legal procedure took more than two months to be completed, the firm can apply to the Public Administration for a reimbursement of all intermittent wages exceeding that period. In 2002, the system of intervening wages was changed $^{10}$, introducing a new rule to transfer severance payments from the firm to the worker: Firms that immediately (i.e. within two days) pay to their dismissed wor$\operatorname{ker}(\mathrm{s})$ the amount that would have been due in case of an unfair dismissal (45 days per year of seniority) do not have to pay any intermittent wages even if the worker files a suit against the firm for unfair dismissal. In this situation, the firm recognises de facto that the dismissal was unfair (because it paid to the worker the amount it has to pay in case of an unfair dismissal), but it can save the costs associated with the intermittent wages in case the worker wants to go to court. However, as the worker has received the largest possible amount of severance pay, why should he/she go to court? Therefore, the new regulation introduces strong incentives to compensate dismissed workers before they to go to court and even before the bargaining institutions get involved. ${ }^{11}$

As there are clear incentives for an improper use of disciplinary reasons, the majority of all dismissal cases are solved by agreement (for example, in 2002, only $22.8 \%$ of all individual dismissals reached the judicial stage). Presumably, in many cases the parties even explicitly declare that disciplinary reasons did not play a role in the firm's decision as this entitles the worker to receive unemployment benefits. Moreover, such agreement avoids any stigma for the worker that usually comes with a dismissal for disciplinary reasons ${ }^{12}$.

${ }^{9}$ See Malo (2000) for a quantitative analysis comparing the impact of the new permanent contract with the old one.

${ }^{10}$ This reform of the intermittent wages was introduced in a very surprising way - through an unemployment benefits act (the 45/2002 Act on the reform of the unemployment benefits system). See García-Perrote (2003) for the legal details of this reform.

${ }^{11}$ See Malo and Toharia (2008) for a detailed analysis of the legal reform implemented in 2002 and its impact on the incentives to solve most dismissals before going to the courts and even before turning to the mediation institutions.

${ }^{12}$ Even when a disciplinary dismissal is declared as fair, the worker can receive unemployment benefits and subsidies, but only after a waiting period of three months. Empirical evidence on the "stigma effects" of individual dismissals - as opposed to mass layoffs - is provided by Gibbons and Katz (1991). Hu and Taber (2007) confirm these findings for white men in the US, but not for black men or for women. No such effects are found by Grund (1999) for Ger- 
In case that more than $10 \%$ of a firm's workforce is affected by a dismissal, the firm is obliged to use a procedure called Expediente de Regulación de Empleo, i.e. a collective dismissal. The most distinctive feature of this procedure in Spain is the requirement of explicit administrative approval, introducing considerable bureaucratic costs for this type of dismissal ${ }^{13}$. If management reaches an agreement with the workers' representatives, the collective dismissal is always approved. If there is no agreement, the Public Administration decides. The most important issue in this context is the amount of severance pay, where a minimum of 20 days per year of seniority is required. Although detailed data has not yet been made available, most commentators assume that the financial compensation that is paid to the workers in this case is significantly higher than in the case of individual dismissals, making collective dismissals the most expensive form of employment adjustment in Spain (Toharia and Ojeda 1999).

\subsection{Labour Courts in Germany and Spain}

In both countries the percentage of workers who go to court after they have been dismissed is quite similar: While in Spain it is one out of ten workers, the respective figure for Germany is one out of seven (Galdón-Sánchez and Güell 2004: 45 and Pfarr et al. 2005: 60) ${ }^{14}$.

Initially, the intention of the DPA was to prohibit dismissals that are not motivated by good reasons. More recently, however, the labour courts have been inclined to sanction dismissals in general. Since the DPA mainly consists of rather general clauses, labour law is actually made by the judges.

In general, the costs for unjust dismissal suits are quite low in Germany. First, labour court fees are lower than other court fees (the maximum at a court of first instance is about $500 €$ ). Second, each party has to bear its own lawyer's fee with the fees depending on the value in dispute. Moreover, at least in the first instance the parties are not required to have a lawyer. Finally, insurance for legal protection (including labour suits) is available at low cost (about 50-100 € per year).

In Germany, more than $95 \%$ of all cases have been brought to the labour courts by either an individual worker, a works council or a trade union. There is,

many. Malo (2000) explains that this stigma effect does not exist in Spain, because dismissals on economic grounds are usually disguised as disciplinary dismissals.

${ }^{13}$ The administrative authorization was required in France until 1986 too, when the Chirac government finally eliminated this requirement.

14 The figure for Spain covers the period 1986-2003, the one for Germany the period 1998-2003. In 1978 (a boom period in Germany), the respective figure was 8\% only (see Falke et al. 1981: $367)$. 
however, no information on the percentage of cases settled in favour of either of the parties.

For Spain, on the other hand, we have information on how the lawsuits proceed through the judicial system: In 2002, for example, about $70 \%$ of all cases dealt with by the conciliation bodies (268.000) ended with an agreement ${ }^{15}$. Of the 71.000 cases that could not be settled by conciliation, about $85 \%$ went to the second instance ("conciliation at social court"), where only a small minority $(27 \%)$ ended with an agreement ${ }^{16}$.

Figure 1

The Structure of a Typical Grievance Procedure Concerning an Individual Dismissal in Germany

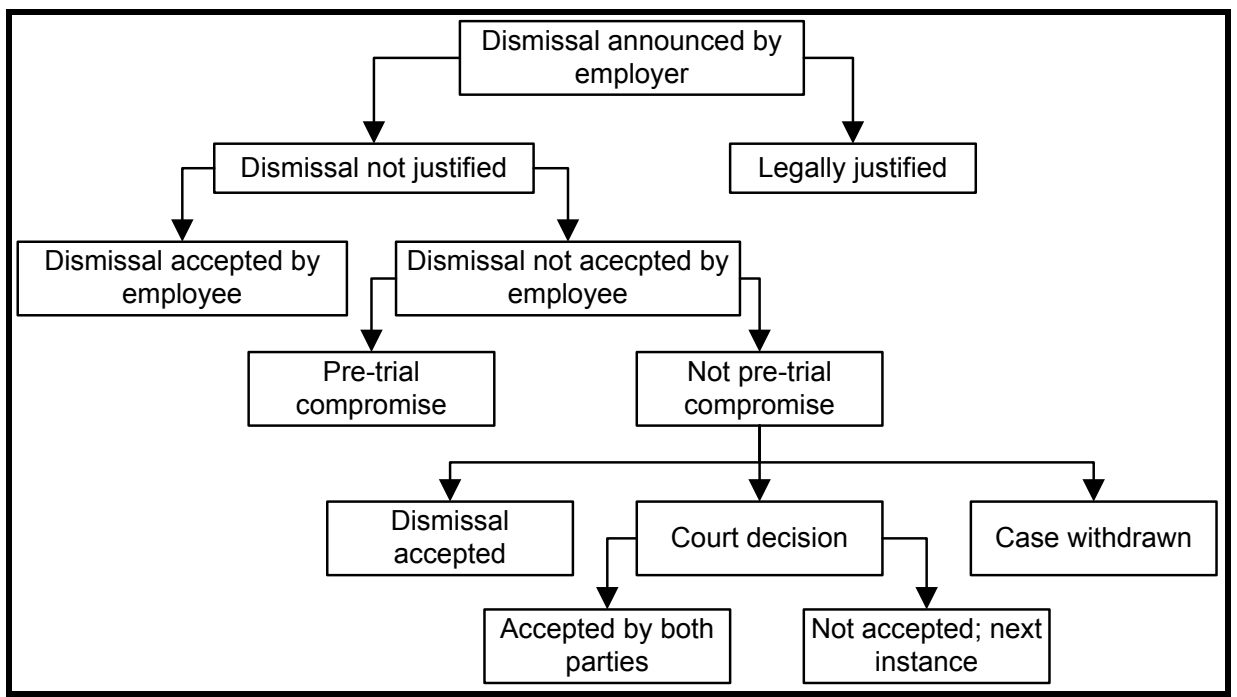

Source: Frick and Schneider (1999: 161).

The remaining 27.000 cases went to a tribunal where the success probability of workers is quite high: About $75 \%$ of the cases decided at this instance are in favour of the employee. Although information on the monetary costs of workers going to the labour court is not available, anecdotal evidence suggests that these are rather low, even when workers hire a legal expert as in most cases workers

15 Another 10.000 cases ended because the workers gave up and withdrew from the court system (see Galdón-Sánchez and Güell 2004: 47).

${ }^{16}$ At this stage again, a large number of cases (17.000) ended because the workers gave up and withdrew their suit (see Galdón-Sánchez and Güell 2004: 47) 
ask their union for legal advice (which is included in union membership, the costs of which are 10 to $15 €$ per month).

Figure 2

The Structure of a Typical Grievance Procedure Concerning an Individual Dismissal in Spain

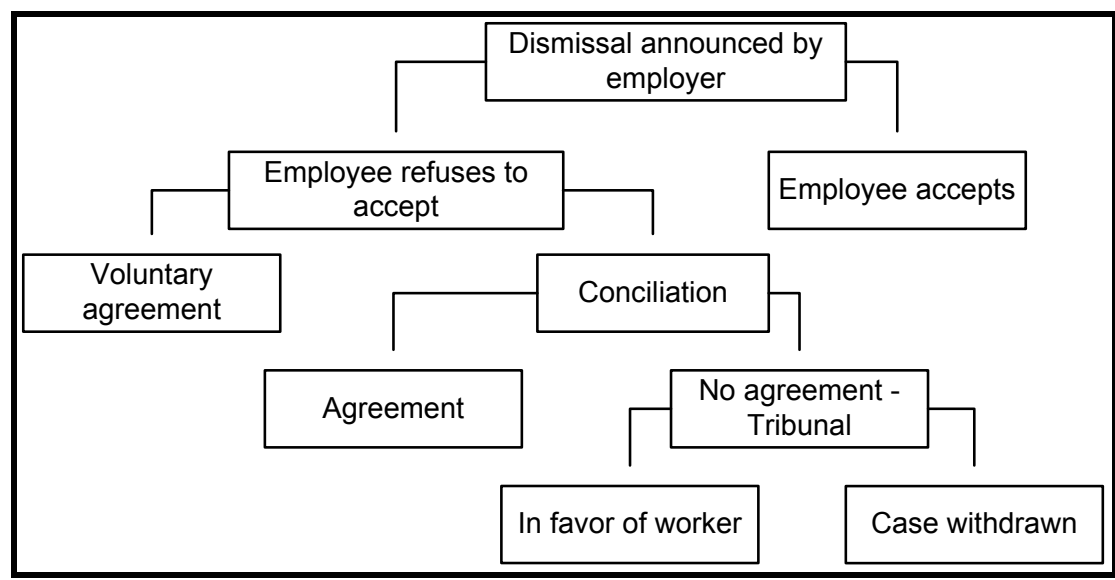

Source: Figure based on Galdón-Sánchez and Güell (2004: 47).

\section{THEORY}

As the general economic situation changes, the individual's opportunity costs of losing the job change, too. This, in turn, clearly affects an individual's probability to go to court in case of a dismissal.

If average unemployment duration increases and/or the percentage of the unemployed returning to the labour market decreases, a higher probability of filing a suit against the employer is to be expected. This is also the case if the average duration of the entitlement for unemployment benefits is reduced, if the "replacement rate", i.e. the level of these benefits, is shortened and/or if the part of the workforce entitled to receive such benefits declines (i.e. because the amount of time that has to be spent in employment before benefits can be claimed has been increased).

Thus, an individual threatened to lose his/her job due to a dismissal will incur costs of unemployment that are mainly determined by the expected duration of the unemployment spell times the expected earnings loss while unemployed.

$$
\text { (1) } \mathrm{EC}_{\mathrm{U}}=\mathrm{ED}_{\mathrm{U}} * \mathrm{EEL}_{\mathrm{U}}
$$

where $\mathrm{EC}_{\mathrm{U}}$ corresponds to individual costs of unemployment, $\mathrm{ED}_{\mathrm{U}}$ to the duration of unemployment, and $\mathrm{EEL}_{\mathrm{U}}$ denotes the earnings loss while unemployed. 
The earnings loss, in turn, depends on the individual's entitlement for unemployment benefits. The amount of time an individual is entitled to receive such benefits usually depends on the duration of the previous employment spell as well as on the individual's age in Germany and on his/her seniority in Spain ${ }^{17}$ : The longer the spell and/or the older the individual, the longer the entitlement period for this particular type of social security payments. Moreover, the replacement rate may also depend on the family status of the claimant: Both in Germany and Spain, for example, married persons receive higher unemployment benefits than persons without dependents.

The probability to sue the (former) employer is not only affected by an individual's opportunity costs but also by the direct costs that have to be borne in case of a law suit. As these costs are rather low in both countries, access to the labour courts is easy. Moreover, the nominal costs have remained more or less constant in Germany as well as in Spain, implying that the real costs have declined over the years.

Finally, judges at labour courts tend to decide in favour of the worker particularly in case of high unemployment (see Ichino et al. 2003). This, in turn, is an additional incentive to workers to sue their employer in a recession when facing a job loss.

While the costs of access to the labour courts are identical across the country for Spanish as well as German employees, the expected earnings losses while unemployed vary considerably. This, in turn, is mostly due to the differences in the regional unemployment and vacancy rates ${ }^{18}$. We therefore use the observable differences in the regional labour market situation to explain the large variation in the relative number of employees seeking access to the first instance of the labour court system in the two countries.

\section{DATA, ESTIMATION, AND EMPIRICAL FINDINGS}

Ideally, the data to test our hypotheses would be individual court cases with detailed information on the individual worker and his/her employer as well as on local labour market conditions. Unfortunately, however, such data is neither available for Germany nor for Spain. The data we use instead are two balanced panels with 473 (Germany) and 340 (Spain) observations mainly from administrative sources and own calculations from the Labour Force Survey. In the

${ }^{17}$ Obviously, for workers with open-ended contracts, seniority and age are highly correlated.

${ }^{18}$ The age composition of the workforce is more or less constant as is the percentage of married employees. Moreover, the qualification structure and the gender composition do not vary either. 
case of Germany, we have 11 federal states ${ }^{19}$ and 43 years, for which the data on unemployment, vacancies and court cases is available, in the case of Spain, we have the respective figures for the 17 autonomous regions over a period of 20 years (for a similar approach see Brown et al., 1997, and García-Martínez and Malo, 2007).

Figure 3

Grievance Procedures Concerning Dismissals and Remuneration in the Federal States of Germany

(Average Over Years 1964-2006)

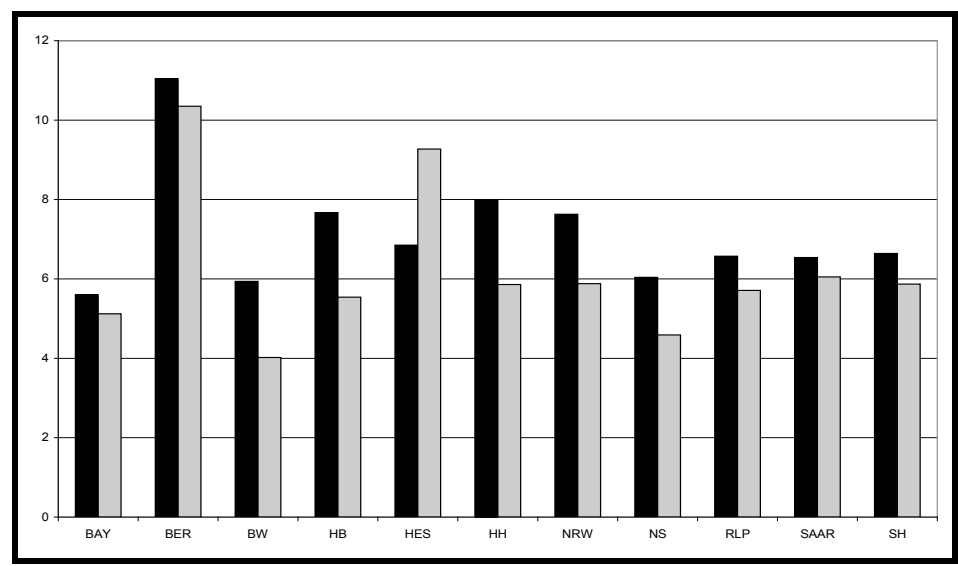

Black: number of grievance procedures concerning dismissals per 1,000 employees. Grey: number of grievance procedures concerning remuneration per 1,000 employees. Abbreviations: $B A Y=$ Bayern; $B E R=$ Berlin; $B W=$ Baden-Württemberg; $H B=$ Bremen; HES = Hessen; $H H=$ Hamburg; NRW = Nordrhein-Westfalen; $N S=$ Niedersachsen; RLP = Rheinland-Pfalz; SAAR = Saarland; $S H=$ Schleswig-Holstein.

Source: Federal Ministry of Labour and Social Affairs ("Bundesministerium fuer Arbeit und Sozialordnung").

It appears from Figure 3 that the number of grievance procedures concerning dismissals varies in Germany across the federal states between less than 6 (Niedersachsen and Baden-Württemberg) and more than 10 per 1,000 employees (Berlin). With regard to the number of cases concerning remuneration issues, the difference between the federal states is considerably higher, ranging

${ }^{19}$ We disregard the four federal states in the former German Democratic Republic where at least in the 1990s other factors than the opportunity costs of losing the job might have affected an individual's probability to go to court. Unfortunately, the data does not allow distinguishing between West and the former East Berlin. 
from 4 cases per 1,000 employees in Baden-Württemberg to about 10 in Ber$\operatorname{lin}^{20}$.

Figure 4

The Development of Grievance Procedures Concerning Dismissals and Remuneration in Germany, 1964-2006

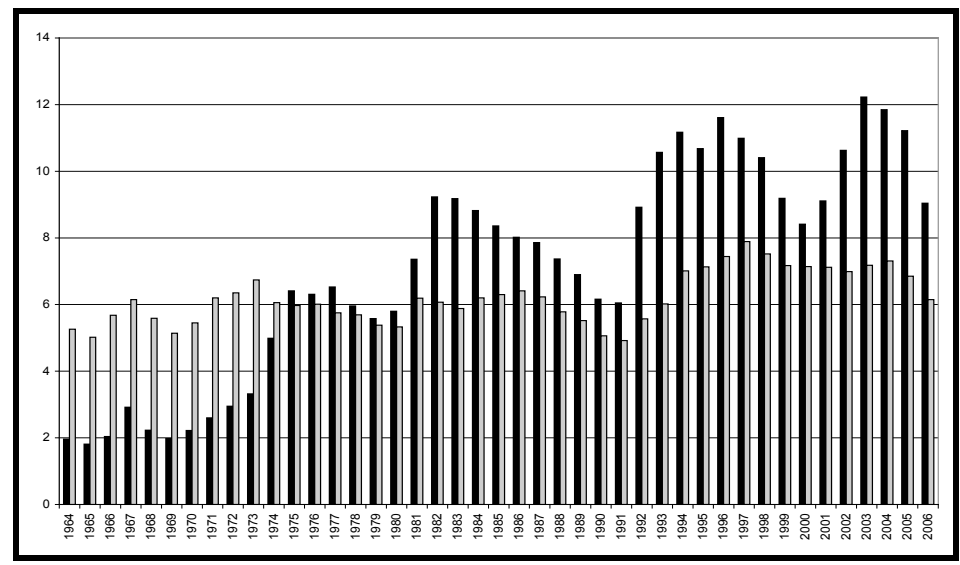

black: number of grievance procedures concerning dismissals per 1,000 employees. grey: number of grievance procedures concerning remuneration per 1,000 employees.

Source: Federal Ministry of Labour and Social Affairs ("Bundesministerium fuer Arbeit und Sozialordnung").

Figure 4 illustrates that the demand for the two different types of grievance procedures is quite different over time: Until the mid 1970s the number of grievance procedures concerning remuneration exceeded the figure for grievance procedures concerning dismissals. Until then, however, the latter figure was always higher than the former (with a rather small difference between the two variables in years with a low unemployment rate and large differences in years with a high unemployment rate).

Thus, the demand for grievance procedures concerning dismissals clearly reflects the developments of the German labour market. However, it is not yet clear whether the seemingly close relationship that can be found at the aggregate level also exists at the level of the federal states, where other factors may turn out to explain the observable pattern much better than the labour market variables we have identified above. Moreover, we expect the labour market variables to be poor predictors of the variation in the demand for grievance pro-

${ }^{20}$ The correlation between the two variables is rather modest $(r=+0.37, p<.01)$ indicating that the determinants are likely to vary. 
cedures concerning remuneration, because of the individual's readiness to sue his/her employer.

Comparing Figures 3 and 5, it appears that the number of grievance procedures concerning dismissals is significantly higher in Spain than in Germany. Moreover, the variation is also larger in the former than in the latter country, ranging from 12 per 1,000 employees in Asturias to 27 in Canarias. Comparable to the situation in Germany, the difference in the number of grievance procedures concerning remuneration is also more pronounced in Spain (ranging from almost 10 cases per 1,000 employees in Extremadura to around 35 in Asturias and País Vasco).

Figure 5

Grievance Procedures Concerning Dismissals and Remuneration in the Autonomous Regions in Spain

(Average Over Years 1987-2006)

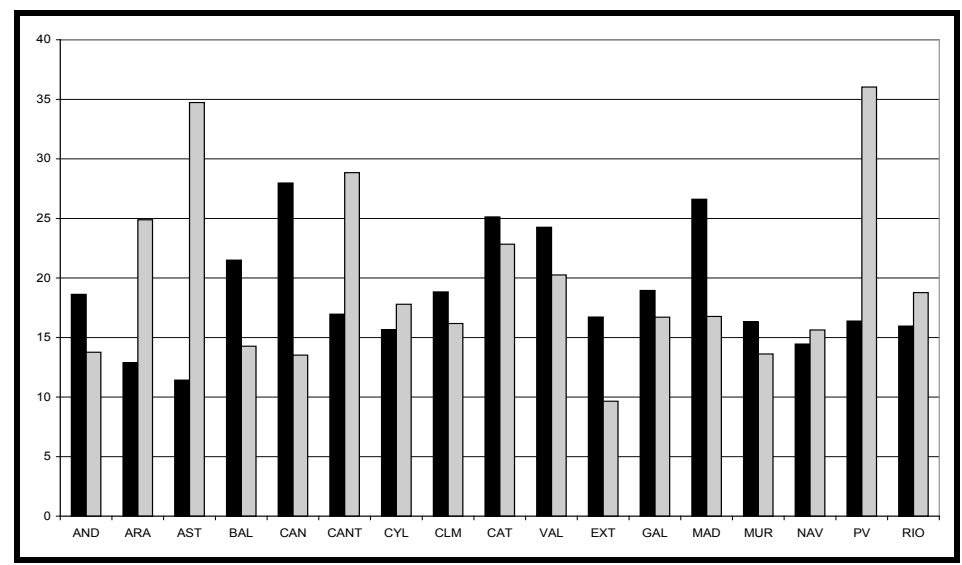

black: number of grievance procedures concerning dismissals per 1,000 employees. grey: number of grievance procedures concerning remuneration per 1,000 employees.

Abbreviations: $A N D=$ Andalucia; $A R A=$ Aragón; $A S T=$ Asturias; $B A L=$ Baleares; CAN = Canarias; $C A N T=$ Cantabria; $C A T=$ Cataluña; $C Y L=$ Castilla $y$ León; $C L M=$ Castilla la Mancha; $V A L$ = Valencia; EXT = Extremadura; $G A L=$ Galicia; $M A D=$ Madrid; MUR = Murcia; NAV = Navarra; $P V=$ País Vasco; RIO = Rioja

Source: Spanish Ministry of Employment and Social Security ("Ministerio de Empleo y Seguridad Social").

As Figure 6 shows, before 2002 the number of grievance procedures concerning dismissals exceeds those concerning remuneration in Spain (with the notable exception of the years 1994 and 1995). Following the passage of the 1997 law which clarifies the use of dismissals on economic grounds, the number of both types of grievance procedures decreased. However, this pattern cannot be observed in each of the autonomous regions to the same extent, in- 
dicating that other circumstances, like economic conditions in general and the regional labour market in particular have a large and persistent effect on individual behaviour. Following the enactment of the 2002 reform affecting the procedure for individual dismissals, the number of grievances due to dismissals are now lower than the number of grievances due to remuneration. As the 2002 legal change considerably increased workers' incentives to accept dismissals and not only avoiding the labour courts but also the mediatory institutions, this clear break in the previous trend can be, at a descriptive level, linked with the legal change of 2002.

Figure 6

The Development of Grievance Procedures Concerning

Dismissals and Remuneration in Spain, 1987-2006

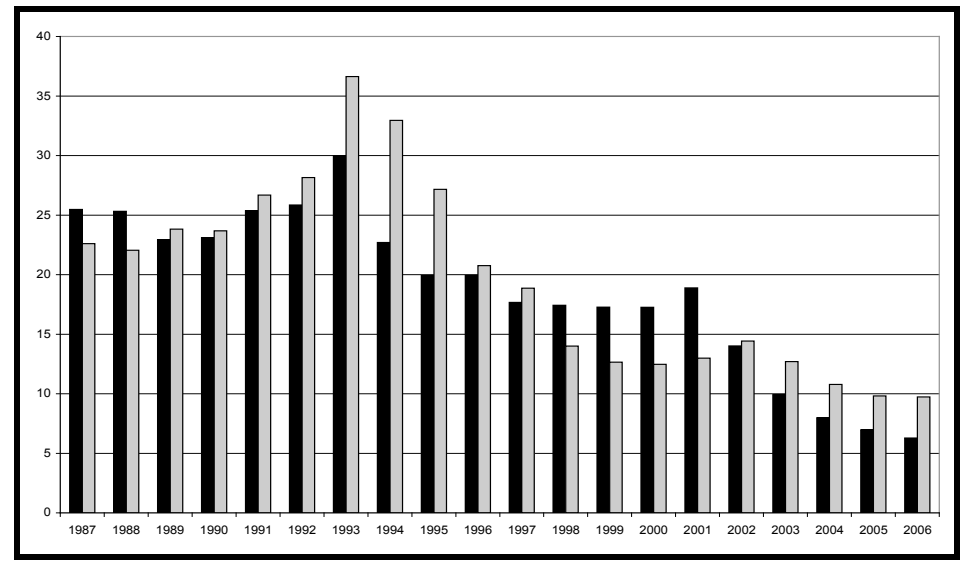

black: number of grievance procedures concerning dismissals per 1,000 employees. grey: number of grievance procedures concerning remuneration per 1,000 employees.

Source: Spanish Ministry of Employment and Social Security ("Ministerio de Empleo y Seguridad Social').

The variables used in the estimations based on German data are as follows:

- Dependent variables:

- GPD: annual number of grievance procedures concerning dismissals divided by average number of employees subject to social security contributions, henceforth "employees" (i.e. disregarding self-employed, civil servants and workers with monthly incomes below the social security threshold $)^{21}$.

${ }^{21}$ The data on grievance procedures was obtained from the Federal Ministry of Labour and Social Affairs ("Bundesministerium fuer Arbeit und Sozialordnung"). 
- GPR: annual number of grievance procedures concerning remuneration divided by average number of employees.

- Explanatory variables:

- Labour market reforms (legal variables):

- WCA: Works Constitution Act (0=no (1964-1972); 1=yes (19732006))

- DPA: Dismissal Protection Act (0=no (1964-1969); 1=yes (19702006))

- Economic situation (business cycle variables):

- SUP: average monthly stock of persons registered as unemployed divided by average number of employees ${ }^{22}$. This variable is calculated in a different way in the German case than in the Spanish one in order to maximize the number of observation available in the time span under consideration.

- SRV: average number of vacancies per month divided by average number of employees.

- TT: linear time trend $(1964=1 \ldots$ 2006=43)

The dummy variables WCA, and DPA are used to capture the effects of the changes in the legal framework, while the rest of variables have a socio-economic nature and serve to quantify the effect of the business cycle.

The variables used in the estimations based on Spanish data are as follows:

- Dependent variables:

- GPD: annual number of grievance procedures concerning dismissals divided by average number of employees subject to social security contributions, henceforth "employees" (i.e. disregarding self-employed, civil servants and workers with monthly incomes below the social security threshold $)^{23}$.

- GPR: annual number of grievance procedures concerning remuneration divided by average number of employees ${ }^{24}$.

- Explanatory variables:

- Labour market reforms (legal variables):

${ }^{22}$ The data on employees, unemployed persons and vacancies were obtained from the Federal Employment Agency ("Bundesagentur fuer Arbeit").

${ }^{23}$ This data comes from an administrative data source collected by the Spanish Ministry of Employment.

${ }^{24}$ Again, the data comes from an administrative data source collected by the Spanish Ministry of Employment. 
- AFD: Acts Fostering the Dismissal of Regular Employees $(0=$ no; $1=y e s(n=3$ different laws that have been enacted in 1994, 1997 and 2002))

- Economic situation (business cycle variables):

- SUP: average unemployment rate (from the Spanish Labour Force Survey following EUROSTAT unemployment definitions).

- SRV: average number of vacancies per month divided by average number of employees ${ }^{25}$.

- TT: linear time trend $(1987=1 \ldots 2006=20)$.

As in the German case, the dummy variables AFD (with different subscripts) are used to capture the effect of the changes in the legal framework, while the rest of the explanatory variabless are socio-economic in nature and serve to quantify the effect of the business cycle.

For both countries, we estimate random effects models ${ }^{26}$, using our balanced regional panel for each country. Estimating the models with panel corrected standard errors or with AR(1) disturbances gives virtually identical results. The results are available upon request. Applying dynamic panel data estimation techniques is not appropriate particularly in the case of Spain because the number of observations per year is rather small.

The models for Germany are of the following general form $(i=$ state; $j=$ year):

$$
\mathrm{gp}_{\mathrm{ij}}=\beta_{0}+\beta_{1} \sup _{\mathrm{ij}}+\beta_{2} \operatorname{srv}_{\mathrm{ij}}+\beta_{3} \mathrm{wca}+\beta_{4} \mathrm{dpa}+\beta_{5} \mathrm{tt}+\varepsilon_{\mathrm{ij}}
$$

where $g \mathrm{p}_{\mathrm{ij}}$ is the number of grievance procedures (either concerning dismissals (gpd) or remuneration (gpr)) per 1,000 employees in state i and year $\mathrm{j}$.

For Spain, the models have the following general form $(i=$ region; $j=$ year) $)^{27}$ :

$$
\operatorname{gp}_{\mathrm{ij}}=\beta_{0}+\beta_{1} \sup _{\mathrm{ij}}+\beta_{2} \operatorname{srv}_{\mathrm{ij}}+\beta_{3} \operatorname{afd}_{1994}+\beta_{4} \operatorname{afd}_{1997}+\beta_{5} \operatorname{afd}_{2002}+\beta_{6} \mathrm{tt}+\varepsilon_{\mathrm{ij}}
$$

${ }^{25}$ The information on vacancies comes from administrative data collected by the Spanish Public Employment Service.

${ }^{26}$ We also estimated fixed-effects models, but statistical tests where in favor of the randomeffects models for both countries.

${ }^{27}$ As a robustness check, we have estimated the regressions for Spain including more control variables, all of them at the regional level and for each year (following García-Martínez and Malo, 2007). We included the percentage of salaried workers with a temporary contract; the percentage of women in the workforce; the percentage of workers younger than 30 years; the distribution of workers by industry (agriculture, industry, construction and services); and the distribution of workers by educational level (mandatory level or less, non-mandatory secondary level, and university). All these variables come from the Labour Force Survey. The results for the main variables included in Tables 1 and 2 retain their sign and are of a similar size. The only variable occasionally changing from significant to non-significant was the time trend. All these estimations are available upon request. 
where $\mathrm{gp}_{\mathrm{ij}}$ denotes the number of grievance procedures (either concerning dismissals (gpd) or remuneration (gpr)) per 1,000 employees in region $\mathrm{i}$ and year $\mathrm{j}$.

These models provide a useful approach to our problem of comparing the relative direct impact of legal variables (changes in labour market regulation) and variables representing economic conditions on the demand for individual grievance procedures ${ }^{28}$.

Table 1 and Table 2 show the results for both countries.

It appears from Table 1 that in the case of Germany the unemployment rate as well as the vacancy rate have the predicted impact on the demand for grievance procedures concerning dismissals: The higher the unemployment rate (vacancy rate), the higher (lower) the relative number of grievance procedures. For Spain, only the unemployment rate has the predicted impact ${ }^{29}$. Perhaps surprisingly, neither the enactment of the Dismissal Protection Act (in 1969) nor the Works Constitution Act (in 1972) seem to have an influence on the demand for either type of grievance procedures in Germany. This is different in Spain, where all of the legal changes have a statistically significant and negative influence on the relative number of grievance procedures. Although both reforms, the 1994 and the 1997 Acts, were introduced to decrease firing costs, the coefficients suggest that the effect is rather small. As many Spanish legal experts have noticed (see, inter alia, Ortega 1995) the term "dismissal on economic grounds" was not well defined and firms were discouraged to use that instrument to adjust their workforces. After the 1997 reform, the situation became clearer as indicated by the lower number of grievance procedures concerning remuneration. However, its effect on the number of grievance procedures concerning dismissals is less pronounced. The dummy variable representing the 2002 reform has the largest coefficient of all three labour market reforms. This, in turn, is not surprising as this reform creates incentives to agree on severance

${ }^{28}$ Of course, other empirical specifications are possible, taking into account non-linear patterns or interactions of legal and economic variables. However, our data does not yet allow such specifications. Moreover, we include in our estimations changes in labour law regimes as dummies. A reasonable hypothesis, however, is that employers as well as workers need some time to learn about how use the new legal rules. Therefore, the impact of changes in labour regulation is unlikely to remain constant over time. However, we leave such specifications for further research with more extensive data (more control variables for the German case) and data covering longer periods of time (for the Spanish case). Another limitation of our empirical approach is that estimated effects are assumed to remain constant over long periods of time. Again, other specifications are possible (requiring e.g. interacting year dummies and the labour market characteristics). Due to a lack of data we have to leave these specifications for further research.

${ }^{29}$ This latter finding is probably due to the fact that in Spain the percentage of vacancies that are reported officially is, first, very low and, second, the publication pattern differs across regions and sectors. The statistical and methodological problems of Spanish vacancy data are discussed by e.g. Antolín (1994). 
payments before going to court and even before going to the bargaining institutions.

Table 1

Determinants of Grievance Procedures Concerning Dismissals in Germany and Spain

(Dependent Variable: Number of Grievance Procedures per 1,000 Employees)

\begin{tabular}{|c|c|c|c|c|}
\hline \multirow{2}{*}{$\begin{array}{l}\text { Country } \\
\text { Variable }\end{array}$} & \multicolumn{2}{|c|}{$\begin{array}{c}\text { Germany } \\
(1964-2006)\end{array}$} & \multicolumn{2}{|c|}{$\begin{array}{c}\text { Spain } \\
(1987-2006)\end{array}$} \\
\hline & B / SE B & $\mathbf{T}$ & B / SE B & $\mathbf{T}$ \\
\hline $\operatorname{SUP}_{\mathrm{t}}$ & $\begin{array}{c}.0155 \\
(.0028)\end{array}$ & $5.43^{* * *}$ & $\begin{array}{c}.0240 \\
(.0073)\end{array}$ & $3.31^{* * *}$ \\
\hline $\mathrm{SRV}_{\mathrm{t}}$ & $\begin{array}{c}-.1132 \\
(.0137)\end{array}$ & $-8.26^{\star * *}$ & $\begin{array}{c}-.0010 \\
(.0008)\end{array}$ & $-1.3+$ \\
\hline $\mathrm{DPA}_{1969}$ & $\begin{array}{c}.0316 \\
(.0331)\end{array}$ & $0.96+$ & --- & \\
\hline $\mathrm{WCA}_{1972}$ & $\begin{array}{c}.0786 \\
(.3857)\end{array}$ & $0.20+$ & --- & \\
\hline $\mathrm{AFD}_{1994}$ & --- & --- & $\begin{array}{l}-.0063 \\
(.0010)\end{array}$ & $-6.46^{\star * *}$ \\
\hline AFD $_{1997}$ & --- & --- & $\begin{array}{l}.0017 \\
(.0009)\end{array}$ & $-1.94^{\star *}$ \\
\hline $\mathrm{AFD}_{2002}$ & --- & --- & $\begin{array}{l}.0079 \\
(.0008) \\
\end{array}$ & $-9.39^{\star \star *}$ \\
\hline TT & $\begin{array}{c}.0135 \\
(.0014)\end{array}$ & $10.00^{* \star *}$ & $\begin{array}{c}.0001 \\
(.0001)\end{array}$ & $0.91+$ \\
\hline CONST & $\begin{array}{c}.3790 \\
(.0551)\end{array}$ & $6.87^{\star \star \star}$ & $\begin{array}{c}.0211 \\
(.0020)\end{array}$ & $10.67^{* * *}$ \\
\hline $\mathrm{N}$ of Cases & \multicolumn{2}{|c|}{473} & \multicolumn{2}{|c|}{340} \\
\hline $\mathrm{N}$ of Regions & \multicolumn{2}{|c|}{11} & \multicolumn{2}{|c|}{17} \\
\hline Cases per Region & \multicolumn{2}{|c|}{43} & \multicolumn{2}{|c|}{20} \\
\hline Wald Chi2 & \multicolumn{2}{|c|}{$1,924.6^{\star \star \star}$} & \multicolumn{2}{|c|}{$1,105.2^{\star \star \star}$} \\
\hline $\mathrm{R} 2$ * 100 & \multicolumn{2}{|c|}{72.2} & \multicolumn{2}{|c|}{54.4} \\
\hline LM-Test & \multicolumn{2}{|c|}{$1,443.7^{\star * *}$} & \multicolumn{2}{|c|}{$1240.2^{\star \star \star}$} \\
\hline Hausman-Test & \multicolumn{2}{|c|}{$0.1+$} & \multicolumn{2}{|c|}{$1.6+$} \\
\hline
\end{tabular}

+ not significant; ${ }^{*} p<.10 ;{ }^{* *} p<.05 ;{ }^{* * *} p<.01$

Source: Authors' database (see the main text).

For an easier comparison of the relative size of the effects of the unemployment rate and the dummy variables representing the various labour market reforms in Spain, we have calculated the corresponding 95\% confidence interval to confirm that the effect of the unemployment rate is always larger (in absolute value) than the impact of the labour market reforms on grievance procedures concerning dismissals. Figure A1 (in the Appendix) provides an illustration of this comparison (where the signs for the labour market reforms have been reversed for an easier comparison). In each case, the confidence interval of the coefficients representing the different labour market reforms never reaches the 
respective interval of the coefficient of the unemployment rate. Thus, the impact of the labour market situation (as proxied by the unemployment rate) is larger than the effect of changes in employment protection legislation. This latter finding corroborates the evidence we find for Germany.

\section{Table 2}

Determinants of Grievance Procedures Concerning Remuneration in Germany and Spain

(Dependent Variable: Number of Grievance Procedures per 1,000 Employees)

\begin{tabular}{|c|c|c|c|c|}
\hline \multirow{2}{*}{$\begin{array}{l}\text { Country } \\
\text { Variable }\end{array}$} & \multicolumn{2}{|c|}{$\begin{array}{c}\text { Germany } \\
(1964-2006)\end{array}$} & \multicolumn{2}{|c|}{$\begin{array}{c}\text { Spain } \\
(1987-2006) \\
\end{array}$} \\
\hline & B / SE B & $\mathbf{T}$ & B / SE B & $\mathbf{T}$ \\
\hline $\operatorname{SUP}_{\mathrm{t}}$ & $\begin{array}{l}.0275 \\
(.0045)\end{array}$ & $6.00^{\star * *}$ & $\begin{array}{l}.0596 \\
(.0176)\end{array}$ & $3.40^{* * *}$ \\
\hline $\mathrm{SRV}_{\mathrm{t}}$ & $\begin{array}{c}.0697 \\
(.0221) \\
\end{array}$ & $3.16^{\star \star \star}$ & $\begin{array}{l}-.0001 \\
(.0020) \\
\end{array}$ & $-0.07+$ \\
\hline $\mathrm{DPA}_{1969}$ & $\begin{array}{c}.0605 \\
(.0533)\end{array}$ & $1.13+$ & & \\
\hline $\mathrm{WCA}_{1972}$ & $\begin{array}{c}.0007 \\
(.0612) \\
\end{array}$ & $0.01+$ & & \\
\hline $\mathrm{AFD}_{1994}$ & --- & -- & $\begin{array}{l}-.0052 \\
(.0025) \\
\end{array}$ & $-2.06^{* *}$ \\
\hline $\mathrm{AFD}_{1997}$ & --- & --- & $\begin{array}{l}-.0115 \\
(.0023) \\
\end{array}$ & $-4.98^{\star * *}$ \\
\hline $\mathrm{AFD}_{2002}$ & --- & -- & $\begin{array}{l}.0032 \\
(.022) \\
\end{array}$ & $-1.43+$ \\
\hline TT & $\begin{array}{l}-.0062 \\
(.0026) \\
\end{array}$ & $-2.85^{\star * *}$ & $\begin{array}{c}.0007 \\
(.0003) \\
\end{array}$ & $2.15^{\star *}$ \\
\hline CONST & $\begin{array}{c}3887 \\
(.0829) \\
\end{array}$ & $4.69^{\star * \star}$ & $\begin{array}{c}.0129 \\
(.0042) \\
\end{array}$ & $3.10^{* * *}$ \\
\hline $\mathrm{N}$ of Cases & \multicolumn{2}{|c|}{473} & \multicolumn{2}{|c|}{340} \\
\hline $\mathrm{N}$ of Regions & \multicolumn{2}{|c|}{11} & \multicolumn{2}{|c|}{17} \\
\hline Cases per Region & \multicolumn{2}{|c|}{43} & \multicolumn{2}{|c|}{20} \\
\hline Wald Chi2 & \multicolumn{2}{|c|}{$56.1^{\star \star *}$} & \multicolumn{2}{|c|}{$190.3^{* * *}$} \\
\hline $\mathrm{R} 2$ * 100 & \multicolumn{2}{|c|}{10.0} & \multicolumn{2}{|c|}{21.1} \\
\hline LM-Test & \multicolumn{2}{|c|}{$1,013.8^{* * *}$} & \multicolumn{2}{|c|}{$297.0^{* \star *}$} \\
\hline Hausman-Test & \multicolumn{2}{|c|}{$0.3+$} & \multicolumn{2}{|c|}{$15.48^{* * *}$} \\
\hline
\end{tabular}

+ not significant; ${ }^{*} p<.10 ;{ }^{* *} p<.05 ;{ }^{* * *} p<.01$

Source: Authors' database (see the main text).

The time trend is statistically significant only for Germany, but its effect is quite small in the case of Spain. This is, nevertheless, indicative of decreasing costs of access to the labour courts of first instance in Germany that might reflect the availability of legal insurance against dismissal for an increasing part of the workforce in both countries. 
In order to check the plausibility of our findings we also estimate the impact of the labour market and labour law variables on the demand for grievance procedures concerning remuneration in both countries (Table 2). We expect our theoretical model to explain the variation in the demand for grievance procedures concerning dismissals much better than the variation in those cases where remuneration is the subject of the conflict between employer and employee. It appears that again the unemployment rate has a statistically significant impact on the number of grievance procedures with the coefficient for Spain having almost twice the size of the coefficient for Germany. Moreover, the coefficient of the vacancy rate retains its significance for Germany, but changes its sign. This implies that in this country an increase in the vacancy rate "encourages" workers to sue their employers in the case of a dispute concerning remuneration (i.e. the availability of an "exit option" leads to the expected change in behaviour).

In the case of Spain, we find that the earlier reforms - the 1994 and the 1997 Act - have a statistically significant impact on the number of court cases and that the coefficient of the 1997 reform is larger than in the case of grievance procedures concerning dismissals. Interestingly, the coefficient of the dummyvariable representing the 2002 Act is no longer significant. Again, the $95 \%$ confidence intervals are displayed in a separate figure (see A2 in the Appendix). Obviously, the impact of the labour market situation (i.e. the unemployment rate) is once more considerably larger than the effect of labour market reforms, as none of the intervals of the coefficients of the reform dummies overlaps or reaches the confidence interval of the coefficient of the unemployment rate.

Summarizing, we emphasize that the results for our key variables representting changes in economic conditions (unemployment and vacancies) are quite similar in the two countries. This is surprising insofar as labour market outcomes in Germany and Spain have been markedly different during our observation period. Moreover, the observed changes in the two labour law regimes have addressed different aspects of employment protection legislation, leading us to assume that their impact should be different. However, comparing the results for the two countries it appears that the estimated impacts of labour law reforms are negligible (almost no effects for Germany and quite small effects for Spain). The impact of economic variables (here in particular the unemployment rate) is, however, far more pronounced. Thus, our findings support the main hypothesis proposed at the beginning of this article that changes in economic conditions affecting the individual costs of a dismissal are a more important determinant of labour litigation than changes in labour law regimes. In fact, as we take a longer period firms and workers will learn to use in a more efficient way (according to their individual objectives and restrictions). So far, changes in the legal infrastructure of the national labour market in both countries have been marginal in nature. Neither the German nor the Spanish government has enacted legislation 
that reduces basic workers' rights and/or dramatically increases the expected earning losses in case of a dismissal. Thus, it is no surprise that the recent legal changes have a minor or even no effect at all on the demand for individual grievance procedures.

\section{CONCLUSIONS}

Our empirical analysis for Germany and Spain shows that labour market characteristics - such as the regional unemployment rate and the vacancy rate, but primarily the former one - have a much stronger influence on the cyclical demand for grievance procedures than changes in the "legal infrastructure" of the labour market. Our underlying hypothesis is based on the assumption that the probability to sue the former employer depends on the opportunity costs (i.e. the foregone earnings while unemployed minus the unemployment benefits received) and on the direct costs to be borne in the case of a law suit. While the costs of access to the labour courts are relatively low and constant across both countries, the expected earning losses vary considerably and so does the number of grievance procedures across the regions within each of the countries with the same legislation.

Furthermore, our estimations demonstrate that - despite the differences in the legal framework - in both countries the impact of labour market conditions on the number of grievance procedures is significantly larger than that of the regulatory framework. In the case of Spain, labour market reforms also show statistically significant effects although these effects are not always consistent with the intentions of the legislator.

The article has some relevant policy implications: First, the enactment of legal regulations restricting dismissals is not a simple matter. The incentives provided and the adequacy of the practical impact of its application to the target pursued by the legislator should be carefully analysed before implementing any legal reform. The true costs of dismissals and their effects on the labour market should be examined taking into account their effective enforcement by the system of labour courts on the one hand and the economic circumstances in each country on the other hand.

Individual costs borne by individual workers are the most important variable affecting the evolution of grievances in both countries. Therefore, the performance of labour market institutions (such as labour courts and mediation institutions) is only slightly affected by changes in employment protection legislation. Employment protection legislation has a relatively small impact on the behaviour of individual workers and sometimes the effects induced by this kind of legislation are even contrary to the legislator's intentions. Nevertheless, non-linear impacts of labour market regulation over time are plausible and, therefore, further research that distinguishes between short- and long-term 
effects (these can be quite different) is urgently required. Moreover, studying the interaction between changes in labour law and economic conditions is also a pending issue for further research that is closely linked to (presumably varying) impact of labour market reforms over time.

\section{REFERENCES}

ADDISON, J.T., and TEIXEIRA P. (2003a): The Economics of Employment Protection. Journal of Labour Research, 24, pp. 85-129.

ADDISON, J.T., and TEIXEIRA P. (2003b): What Have We Learned about the Employment Effects of Severance Pay? Further Iterations of Lazear et al., Discussion Paper No. 943, Institute for the Study of Labour, Bonn.

ANTOLÍN, P. (1994): Unemployment Flows and Vacancies in Spain, Instituto Valenciano de Investigaciones Económicas (IVIE), Working Paper 94-05, Valencia. Freely available: http://www.ivie.es/downloads/docs/wpasec/ wpasec-1994-05.pdf

BAUER, T., BENDER S., and BONIN H. (2004): Dismissal Protection and Worker Flows in Small Establishments, Discussion Paper No. 1105, Institute for the Study of Labour, Bonn.

BENTOLILA, S., and DOLADO, J.J. (1994): Labour Flexibility and Wages: Lessons from Spain. Economic Policy, 9, pp. 53-99.

BERGER, H. (1998): Regulation in Germany: Some Stylized Facts about its Time Path, Causes and Consequences. Zeitschrift für Wirtschafts- und Sozialwissenschaften, 118, pp. 185-220.

BOERI, T., and JIMENO, J.F. (2005): "The effects of employment protection: Learning from variable enforcement". European Economic Review, 49(8), pp. 2057-2077.

BOTERO, J., DJANKOV, S., LA PORTA, R., LOPEZ-DE-SILANES, F., and SHLEIFER, A. (2004): The Regulation of Labor. Quarterly Journal of Economics, 119, pp. 1339-1382.

BROWN, S., FRICK B., and SESSIONS J. (1997): Unemployment, Vacancies and Unfair Dismissals. Labour, 11, pp. 329-349.

CHOR, D., and FREEMAN, R. (2005): The 2004 Global Labor Survey: Workplace Institutions and Practices Around the World. National Bureau of Economic Research, Working Paper 11598.

DEAKIN, S., and SARKAR, P. (2008): Assessing the long-run economic impact of labour law systems: a theoretical reappraisal and analysis of new time series data. Industrial Relations Journal, 39, pp. 453-487. 
EGER, T. (2004): Opportunistic Termination of Employment Contracts and Legal Protection against Dismissal in Germany and the USA. International Review of Law and Economics, 23, pp. 381-403.

FALKE, J., HÖLLAND, A., RHODE, B., and ZIMMERMANN, G. (1981): Kündigungspraxis und Kündigungsschutz in der Bundesrepublik Deutschland, Bonn: Bundesministerium für Arbeit und Sozialordnung

FELDMANN, H. (2003): Labour Market Regulation and Labour Market Performance: Evidence Based on Surveys among Senior Business Executives. Kyklos, 56, pp. 509-540.

FRICK, B., and SCHNEIDER M. (1999): Zunehmende Konfliktregulierung durch Arbeitsgerichte? in: Backes-Gellner, U. et al. (eds.): Entlohnung und Arbeitszeitgestaltung im Rahmen betrieblicher Personalpolitik, Munich: Hampp, pp. 157-183.

GALDÓN-SÁNCHEZ, J.E., and GÜELL M. (2003): Dismissal Conflicts and Unemployment. European Economic Review, 47, pp. 323-335.

GALDÓN-SÁNCHEZ, J.E., and GÜELL M. (2004): Let's Go to Court: Firing Costs and Dismissal Conflicts, unpublished manuscript, Universitat Pompeu Fabra, Barcelona.

GARCÍA-SERRANO, C., MALO, M.A. and PÉREZ-INFANTE, J.I. (2010): Dos cuestiones clave de la reforma laboral: Despidos y negociación colectiva, Temas Laborales, 107, pp 53-85.

GARCÍA-MARTÍNEZ, P., and MALO M.A. (2007): The Strategic Use of Dismissal Legislation: An Empirical Analysis Using Spanish Data. European Journal of Law and Economics, 23, pp. 151-167.

GARCÍA-PERROTE, I. (2003): La Ley 45/2002 de Reforma de la Protección por Desempleo. La reforma de la reforma del despido, de los salarios de tramitación y del desempleo, Valladolid: Editorial Lex Nova.

GIBBONS, R., and KATZ L.F. (1991): Layoffs and Lemons. Journal of Labour Economics, 9, pp. 351-380.

GOERKE, L., and PANNENBERG M. (2005): Bargaining in the Shadow of the Law: Severance Pay in West Germany, unpublished manuscript, Department of Economics, University of Mainz.

GRUND, C. (1999): Stigma Effects of Layoffs: Evidence from German MicroData. Economic Letters, 64, pp. 241-247.

GRUND, C. (2006a): Overcompensation by Severance Payments. Applied Economics, 38, pp. 925-930.

GRUND, C. (2006b): Severance Payments for Dismissed Employees in Germany. European Journal of Law and Economics, 22, pp. 49-71.

HESELER, H., and MÜCKENBERG U. (1999): The Management of Redundancies in Europe: The Case of Germany. Labour, 13, pp. 183-235. 
HU, L., and TABER C. (2007): Displacement, Asymmetric Information and Heterogeneous Human Capital, Upjohn Institute Staff Working Paper 07-136, Department of Economics, Northwestern University.

ICHINO, A., POLO, M., and RETTORE, E. (2003): Are Judges Biased by Labour Market Conditions? European Economic Review, 47, pp. 913-944.

LAZEAR, E.P. (1990): Job Security Provisions and Employment. Quarterly Journal of Economics, 105, pp. 699-726.

LEVINE, D.I. (1989): Just-Cause Employment Policies When Unemployment is a Worker Discipline Device. American Economic Review, 79, pp. 902-905.

LEVINE, D.I. (1991): Just-Cause Employment Policies in the presence of Worker Adverse Selection. Journal of Labour Economics, 9, pp. 294-305.

MALO, M.A. (2000): A Simple Model of Severance Pay Determination: The Case of Individual Dismissals in Spain. Labour, 14, pp. 269-290.

MALO, M.A., and PÉREZ, J. (2003): Individual Dismissals in Europe and the United States: A Model on the Influence of the Legal Framework on Firing Costs. European Journal of Law and Economics, 15, pp. 47-63.

MALO, M.A., and TOHARIA, L. (2008): The Automatic Nature of Dismissals in Spain: Dismissal-at-will under Civil Law, in: Levin, W.R. (ed.): Political Economy Research Focus, Nova Science Publishers, NY, pp 109-119.

MALO, M.A. (2012): Una primera valoración de la reforma laboral de 2012, Cuadernos de Información Económica, 226.

NICKELL, S., and LAYARD R. (1999): Labour Market Institutions and Economic Performance, in: Ashenfelter, O. and D. Card (eds.): Handbook of Labour Economics, Amsterdam: Elsevier, pp. 3029-3084.

OECD (1999): Employment Protection and Labour Market Performance. Employment Outlook, Paris: OECD, pp. 45-132.

ORTEGA, E. (1995): La extinción de la relación laboural por amortización del puesto de trabajo. Barcelona: Praxis.

PFARR, H., ULLMAN, K., BRADTKE, M., SCHNEIDER, J., KIMMICH, M., and BOTHFELD, S. (2005): Der Kündigungsschutz zwischen Wahrnehmung und Wirklichkeit: Betriebliche Erfahrungen mit der Beendigung von Arbeitsverhältnissen, Munich: Hampp

PIERRE, G., and SCARPETTA S. (2004): Employment Protection Through the Eyes of Employers: Do They Matter and How Do Firms Respond to Them? Discussion Paper No. 1424, Institute for the Study of Labour, Bonn.

TOHARIA, L. and OJEDA, A. (1999) "The management of redundancies in Europe: the case of Spain", Labour, 13 (1), pp. 1-31.

VERICK, S. (2004): Threshold Effects of Dismissal Protection Legislation in Germany, Discussion Paper No. 991, Institute for the Study of Labour, Bonn. 


\section{Appendix}

Figure A1

Coefficients and 95\% Confidence Interval for the Unemployment Rate and Labour Law Reforms in Spain

(Regression with Grievance Procedures Concerning Dismissals as Dependent Variable)

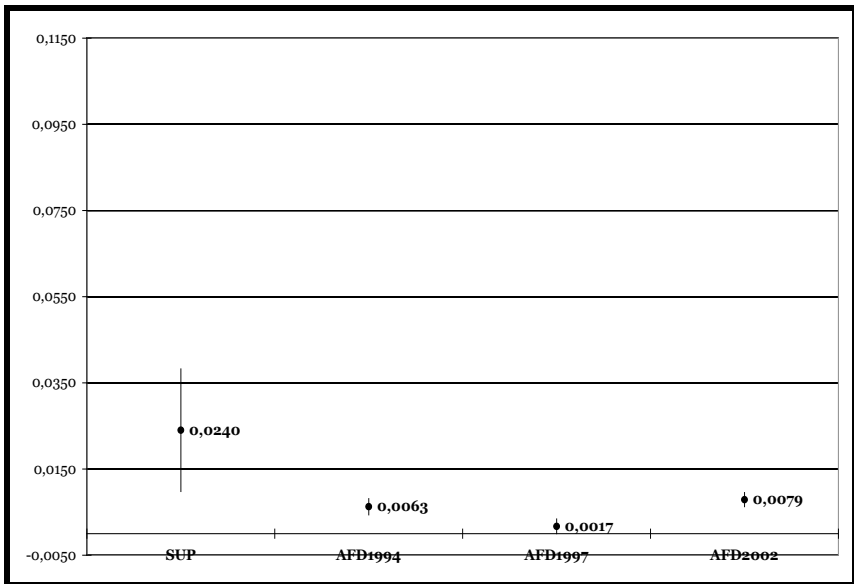

Note: The signs of the dummies representing the different labour market reforms have been reversed for ease of presentation.

Source: Regression of Table 1 (Spain).

Figure A2

Coefficients and 95\% Confidence Interval for the Unemployment Rate and Labour Law

Reforms in Spain

(Regression with Grievance Procedures Concerning Remuneration as Dependent Variable)

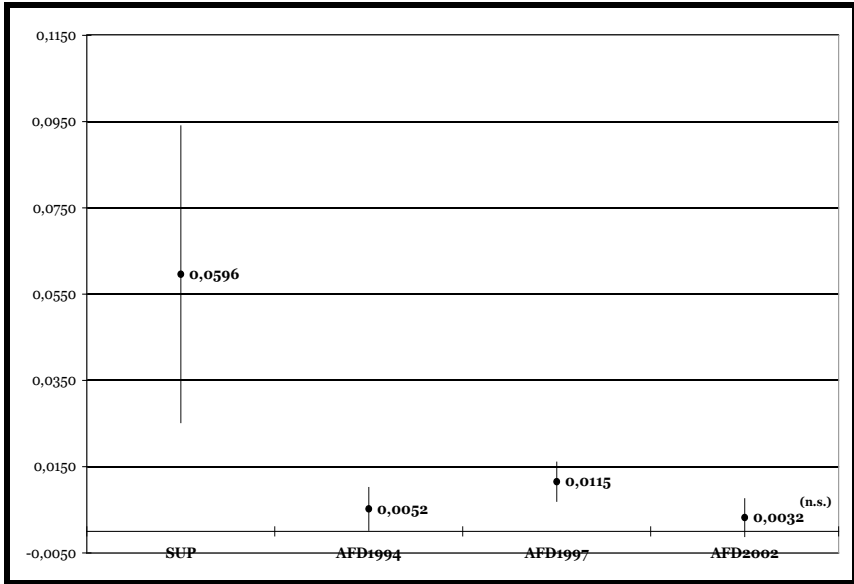

Note: The signs of the dummies representing the different labour market reforms have been reversed for ease of presentation.

n.s.: not statistically significant at conventional levels.

Source: Regression of Table 2 (Spain). 
